\title{
US tosses out patents on three Wisconsin stem cell lines
}

The US government in March moved to revoke three key patents on human embryonic stem cell lines developed by James Thomson, a University of Wisconsin researcher widely considered to be the first to isolate and culture such cells.

If the preliminary ruling is upheld, it could ease scientists' access to the lines for research purposes, consumer advocates say.

"These patents are undeserved and they're causing substantial harm by requiring people to acquire licenses before doing research," says Dan Ravicher, executive director of the Public Patent Foundation, the New York City-based organization that requested the reexamination.

Since the US Patent and Trademark Office granted the first of the patents in 1998, critics have argued that they are too broad and impede research. The Wisconsin Alumni Research Foundation (WARF) holds the three patents under review.

Under the patents, the foundation claims rights to both the method for cultivating primate ES cells and to the cells themselves. WARF has thus far collected $\$ 3.5$ million in licensing fees and will receive royalties for any product developed using the cells—although none have as yet been developed.

Some biotechnology companies say the pricey licensing fees-which can cost hundreds of thousands of dollars-have forced them to take their stem cell research overseas, where the patents don't apply.

But toward academic researchers, "WARF has been recently rather generous," says Christopher Scott, head of Stanford University's Program on Stem Cells and Society.

In January, in response to protests from academia, WARF waived licensing fees for human ES cell research at universities. Academic researchers pay $\$ 500$ per batch of cells. "Currently, the impact of these patents on academic research is negligible," says Scott.

Still, the patents have a "chilling" effect on research by forcing private companies to invest in research abroad, says Ravicher.

Last July, the Public Patent Foundation and the Foundation for Taxpayer and Consumer Rights, both consumer advocate organizations, challenged the patents' validity, arguing that Thomson's work on isolating the cell lines was obvious, given previous research, and therefore didn't deserve a patent. The Patent Office has now agreed with that assertion.

WARF officials are confident that ultimately the patents won't be revoked. “There's a long road ahead," says spokesman Andrew Cohn.

But the preliminary ruling makes it likely that the patents will at least be amended to restrict WARF's control over the process and the cells, says Ravicher. "This is a quite successful and quite strong rejection and it will be difficult for WARF to overcome it."

WARF has 60 days to file its response, after which the patent office will make its decision. WARF can also apply to the Board of Patent Appeals and Interferences and, if necessary, go to federal court. The patents remain active until a final decision is made, which could take up to three years.
For the moment, stem cell researchers face more formidable hurdles, such as launching state programs, says Marc Lalande, who heads the University of Connecticuts Stem Cell Working Group.

But in the long term, the patents could have a big impact if ES cell therapies are developed. For instance, California-based Geron has exclusive rights to heart, nerve and pancreatic cell lines and is developing a human ES cell-based spinal cord injury treatment.

"Worry about the patents being so broad extends deeply into commercial and economic realms," says Scott. "People in the stem cell business are concerned that all roads will lead through WARF and all secondary roads will lead through Geron."

Alisa Opar, New York

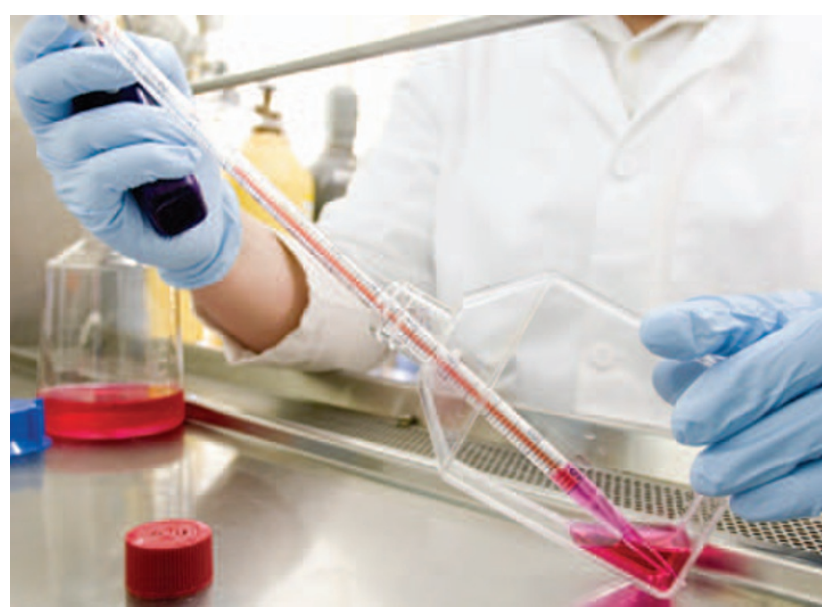

Free cells: Revoking patents on three of the University of Wisconsin's stem cell lines is expected to boost research.

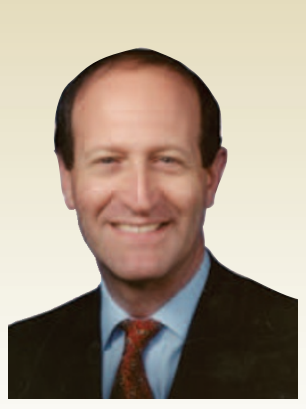

I give it about a 50/50 chance. I wouldn't rule it out. But a one-time therapeutic vaccine is not going to happen.

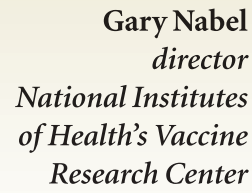

I think that the chances of a partially effective vaccine being licensed for use in humans is low. Hopefully one will be in the pipeline.

Julie Overbaugh

Fred Hutchinson

Cancer Research Center

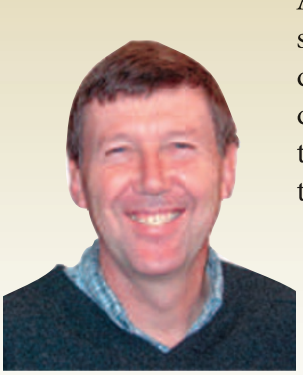

A traditional vaccine like smallpox or polio, I very much doubt it. But something that delays progression to AIDS, there's a reasonable chance of that.

Dennis Burton professor

The Scripps Research Institute 